\title{
Indigenous Peoples and Education in the Russian Federation
}

\section{Zamyatin, Konstantin}

United Nations

2017

Zamyatin , K 2017 , Indigenous Peoples and Education in the Russian Federation . in State pÿof the World s Indigenous Peoples : Education . vol. 3rd, United Nations, New York, pp. 187-206.

http://hdl.handle.net/10138/241955

publishedVersion

Downloaded from Helda, University of Helsinki institutional repository.

This is an electronic reprint of the original article.

This reprint may differ from the original in pagination and typographic detail.

Please cite the original version. 


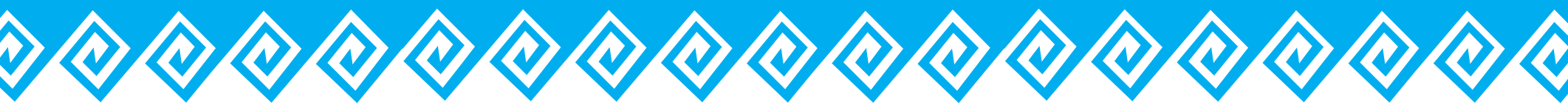

\section{E c O $n \circ \mathrm{m} i c$ \&}
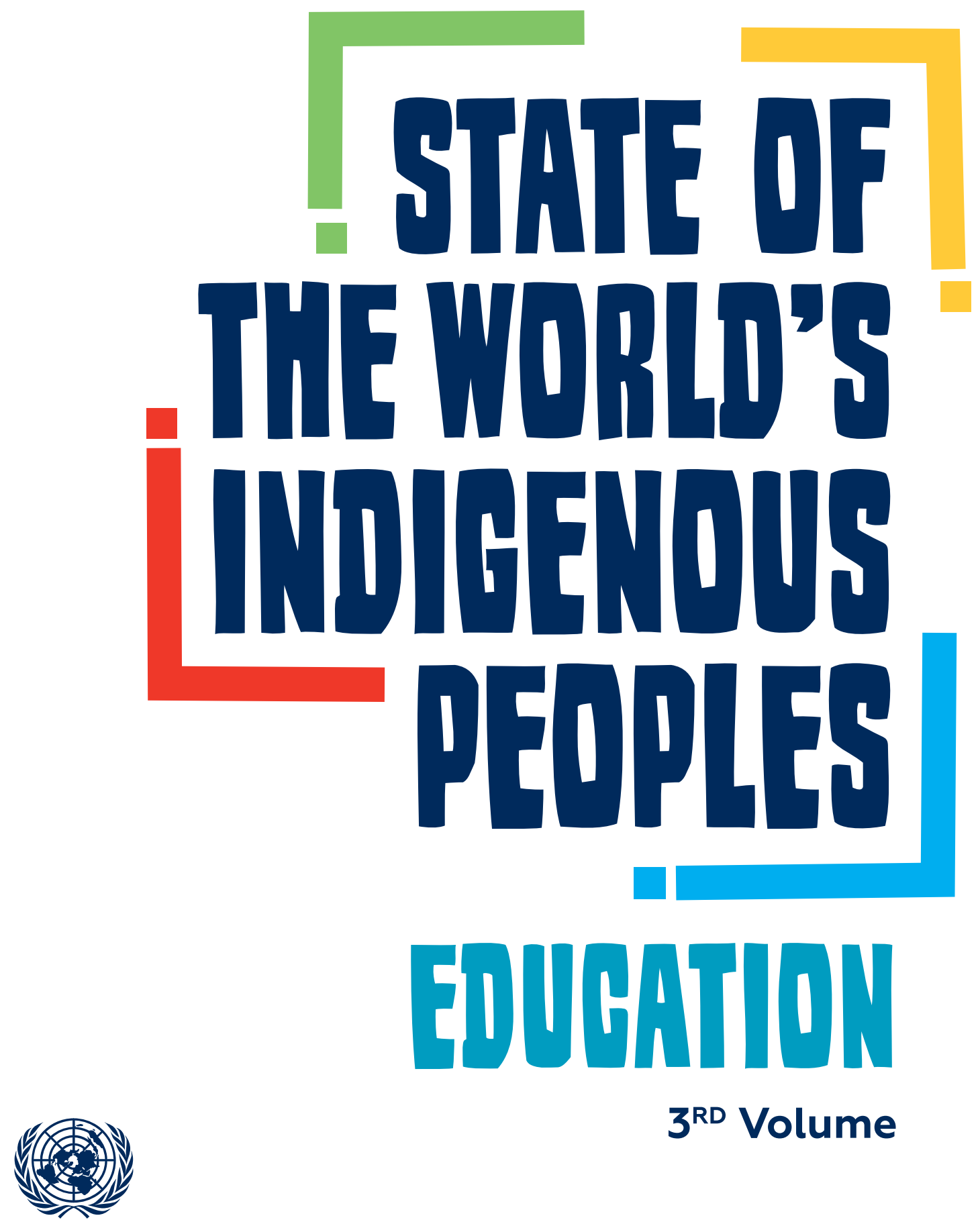

United Nations

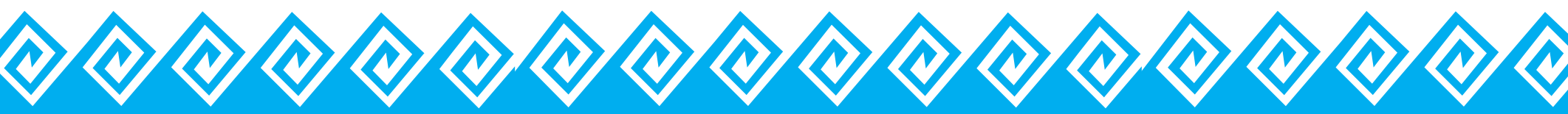


Department of Economic and Social Affairs Division for Social Policy and Development Secretariat of the Permanent Forum on Indigenous Issues
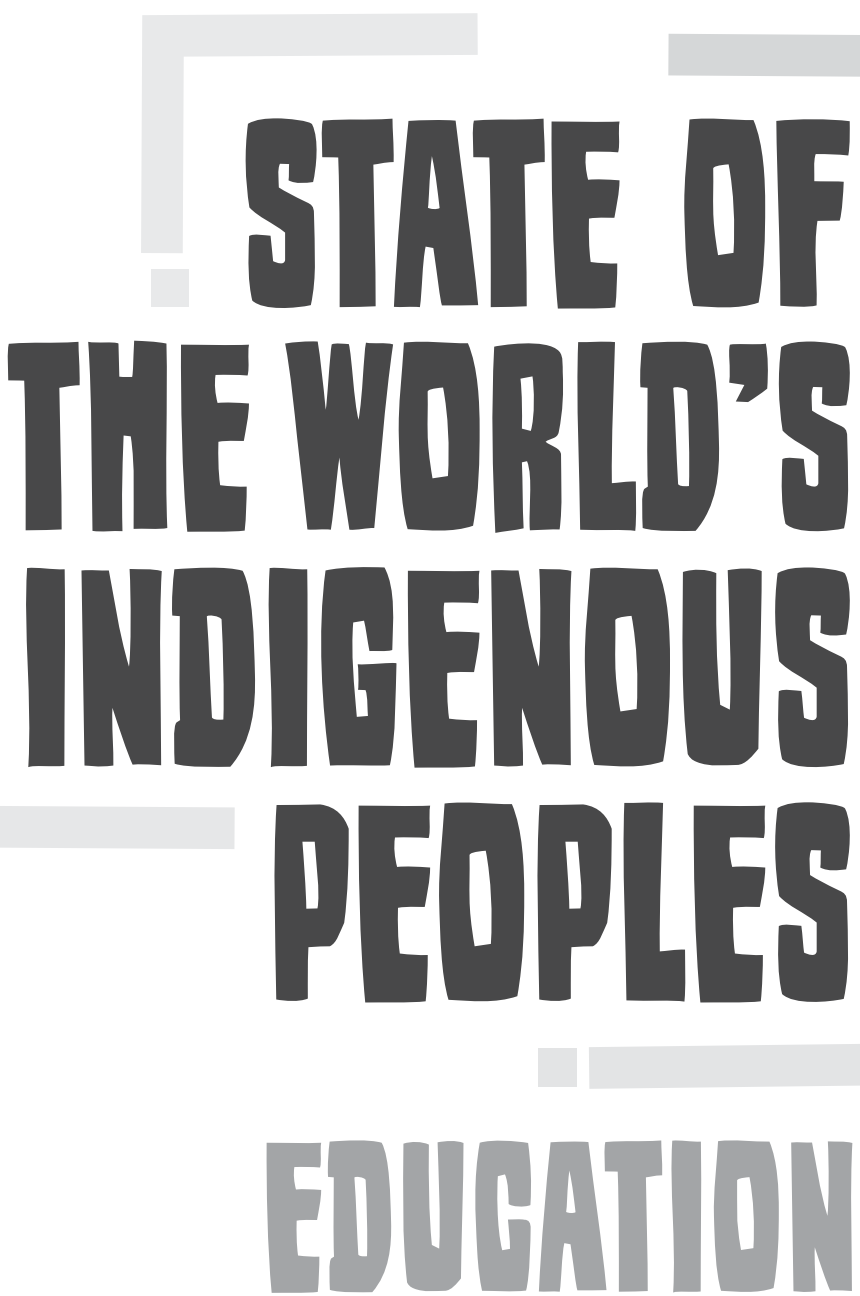

$3^{\text {RD }}$ Volume

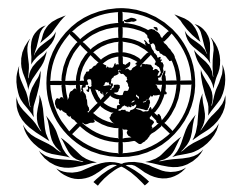

United Nations

New York, 2017 


\section{UN-DESA}

The Department of Economic and Social Affairs of the United Nations Secretariat is a vital interface between global policies in the economic, social and environmental spheres and national action. The Department works in three main interlinked areas: (i) it compiles, generates and analyses a wide range of economic, social and environmental data and information on which States Members of the United Nations draw to review common problems and to take stock of policy options; (ii) it facilitates the negotiations of Member States in many intergovernmental bodies on joint courses of action to address ongoing or emerging global challenges; and (iii) it advises interested Governments on ways and means of translating policy frameworks developed in United Nations conferences and summits into programmes at the country level and, through technical assistance, helps build national capacities.

\section{Note}

The views expressed in the present publication do not necessarily reflect those of the United Nations. The designations employed and the presentation of the material in this publication do not imply the expression of any opinion whatsoever on the part of the Secretariat of the United Nations concerning the legal status of any country or territory or of its authorities, or concerning the delimitations of its frontiers.

The designations of country groups in the text and the tables are intended solely for statistical or analytical convenience and do not necessarily express a judgment about the stage reached by a particular country or area in the development process.

Mention of the names of firms and commercial products does not imply the endorsement of the United Nations.

Symbols of United Nations documents are composed of letters combined with figures.

\section{ST/ESA/368}

United Nations publication

Sales no.: E.17.IV.3

ISBN: 978-92-1-130341-4

elSBN: 978-92-1-362902-4

Copyright (c) United Nations, 2017

All rights reserved

Printed by the United Nations, New York 


\section{Contents}

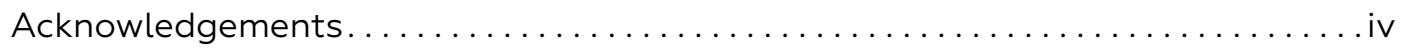

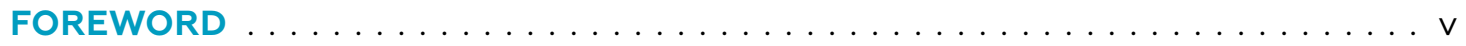

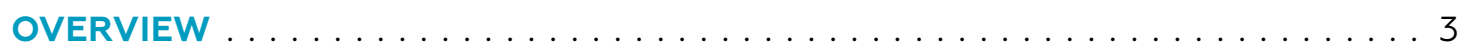

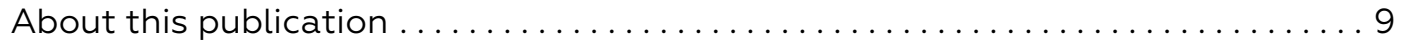

CHAPTER 1: Indigenous peoples and education in the African region $\ldots \ldots \ldots$

Introduction . . . . . . . . . . . . . . . . . . . . . . . . . . . . . . . 15

Indigenous peoples and education in the African region . ................ 16

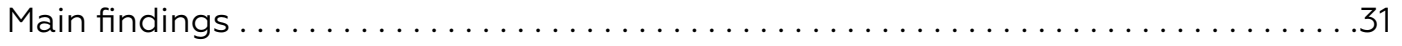

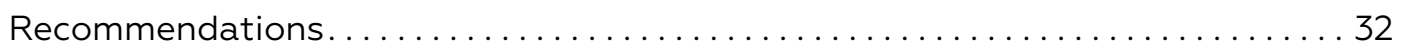

References ................................................ 35

CHAPTER 2: Indigenous peoples and education in the Arctic region . . . . . . . 41

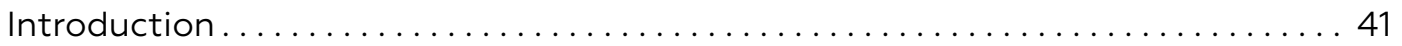

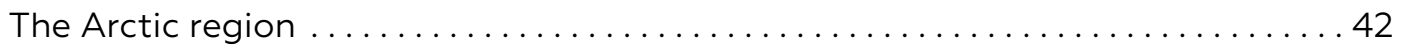

Indigenous peoples and education in the Arctic region. ................ 45

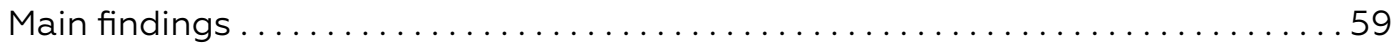

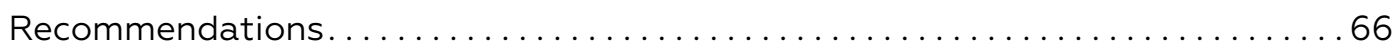

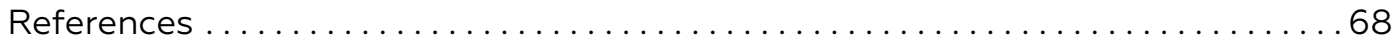

CHAPTER 3: Indigenous peoples and education in Asia . . . . . . . . . . . 77

Introduction . . . . . . . . . . . . . . . . . . . . . . . . . . . . . . . 77

Indigenous peoples and education in the Asian region . . . . . . . . . . . . . . 80

Major issues relating to indigenous peoples and education in Asia . . . . . . . . 83

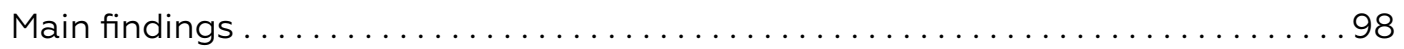

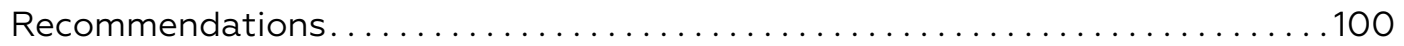

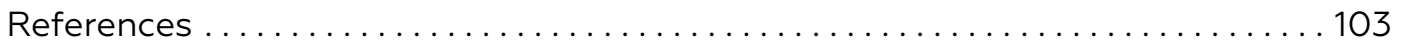

CHAPTER 4: Indigenous peoples and education in Central and South America

and the Caribbean . . . . . . . . . . . . . . . . . . . . . . . . . . . . . . . 109

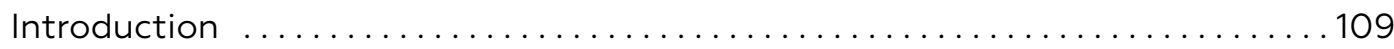

Indigenous peoples and education in Central and South America

and the Caribbean .......................................... 111

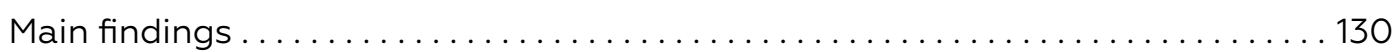

Recommendations.......................................... 134

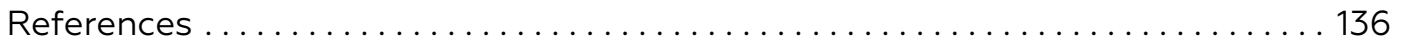


CHAPTER 5: Indigenous peoples and education in the Northern American region . .145

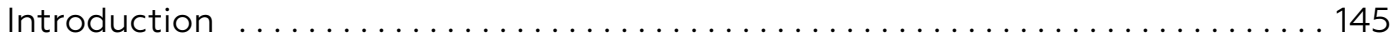

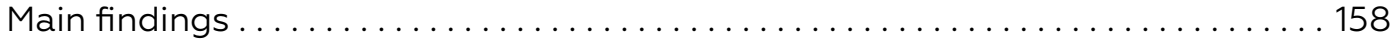

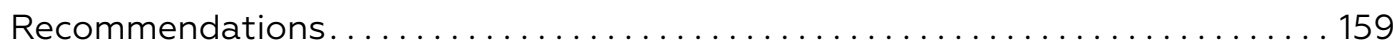

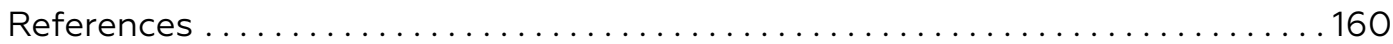

CHAPTER 6: Indigenous peoples and education in the Pacific region . . . . . . . . .165

Introduction . . . . . . . . . . . . . . . . . . . . . . . . . . . . . . . . . . . . . 165

Indigenous peoples and education in the Pacific region . . . . . . . . . . . 166

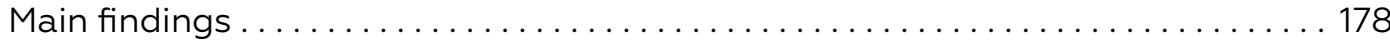

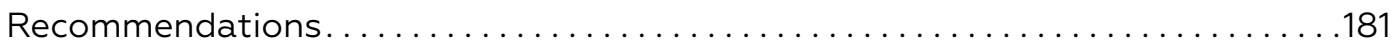

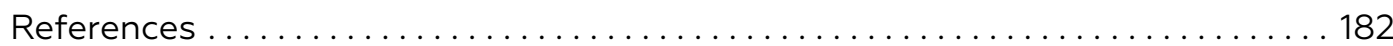

CHAPTER 7: Indigenous peoples and education in the Russian Federation . . . . .187

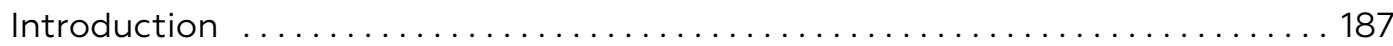

Overview of indigenous peoples in the Russian Federation . . . . . . . . . . . 188

Indigenous peoples and education in the Russian Federation ................ 190

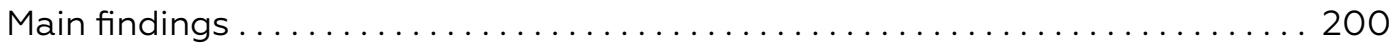

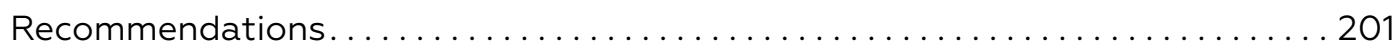

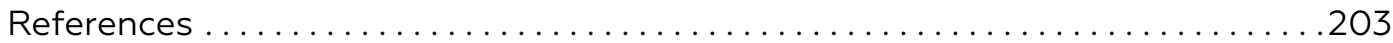

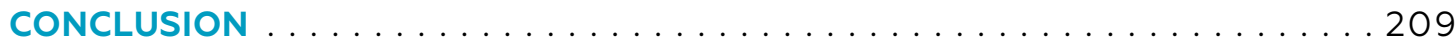

\section{Acknowledgements}

The preparation of State of the World's Indigenous Peoples: Education has been a collaborative effort of experts and organizations. The secretariat of the Permanent Forum on Indigenous Issues within the Division for Social Policy and Development of the Department of Economic and Social Affairs of the United Nations Secretariat oversaw the preparation of the publication. The thematic chapters were written by Monica Aleman Cunningham, Dr. Karla Jessen Williamson and Yvonne Vizina, Prashanta K. Tripura, Juan de Dios Simón Sotz, Dr. Octaviana V. Trujillo, Linda Tuhiwai Smith and Konstantin Zamyatin. Special acknowledgements go to the editors, Birgitte Feiring, who wrote the overview and the final section, entitled "Conclusions", and Michael Brodsky; the translator, Sebastian Vuinovich; and the United Nations Graphic Design Unit of the Department of Public Information. 


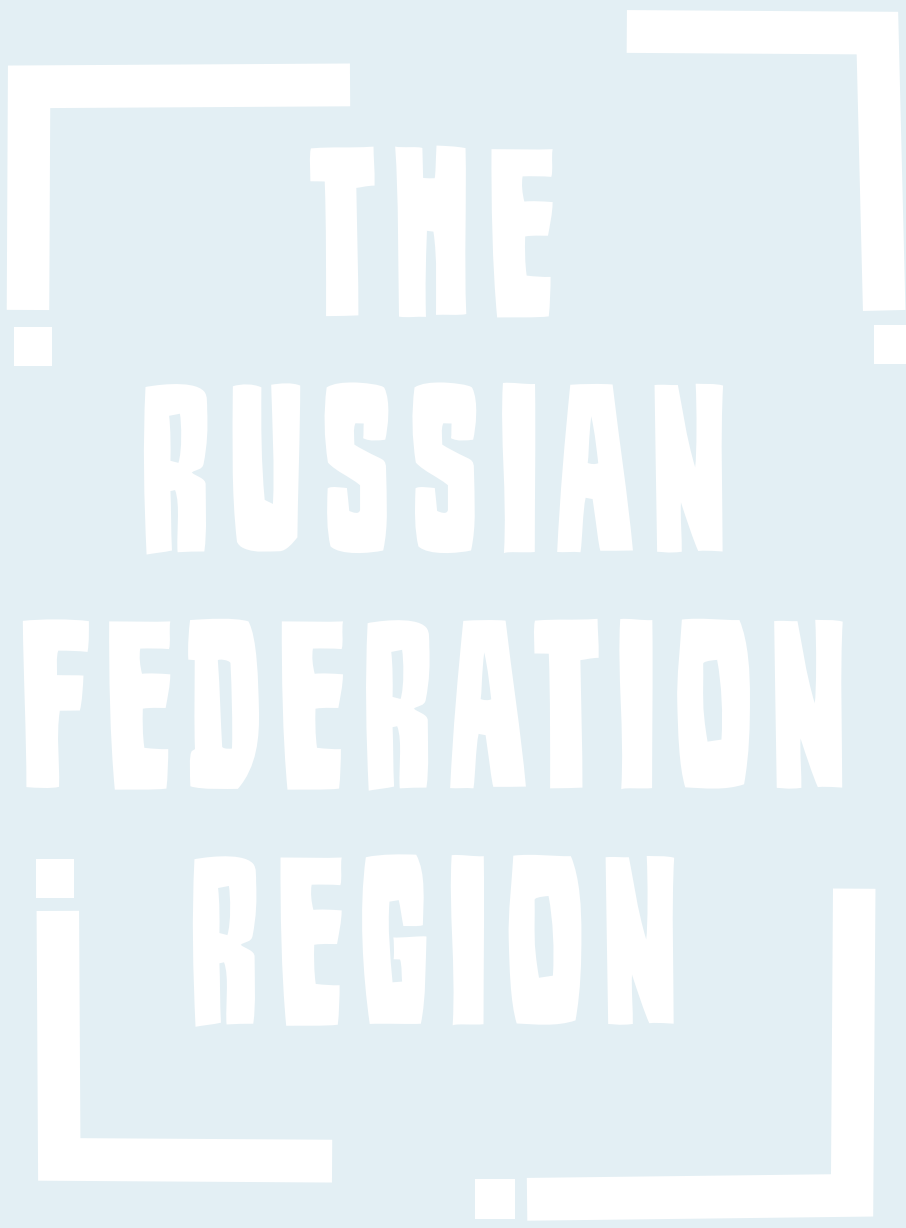




\title{
Chapter VII
}

\section{Indigenous peoples and education in the Russian Federation}

\author{
Konstantin Zamyatin
}

\section{Introduction}

As most self-identified indigenous peoples in the region live in the Russian Federation, the present chapter will focus mainly on them.

In the aftermath of the First World War, the Union of Soviet Socialist Republics (USSR or more commonly known as the Soviet Union) became a federation. Its territorial units were named after "the peoples" who "exercised their right to national self-determination". In addition to the 15 larger titular nations composing the Soviet Union, there were smaller nationalities which acquired their national territories. Federalization was conjoined with the early Soviet policy of 'multiculturalism' within the national entities, whereby the local languages and cultures were promoted in the public domain. For the first time, many languages in northern Russia acquired writing systems. The right to receive an education in one's mother tongue was affirmed and implemented in combination with the policy of universal access to education, which was introduced in 1930. 
In the late 1930s, the multiculturalism policy was put on hold and Russian, which was introduced as a compulsory subject for all, gradually became the medium of instruction. During the 1930s, the arrival of new settlers in the northern regions of the country led to dramatic changes in the lifestyle of indigenous peoples. By the mid-1950s, indigenous communities had witnessed a rapid shift from indigenous languages to Russian. In 1958, through school reform, parents were given the opportunity to choose the languages of instruction in schools. Many small national schools switched en masse to the respective languages of the republics of the Soviet Union and to Russian, with indigenous languages taught only as an optional subject. Boarding schools were introduced where children - including indigenous children - resided away from their parents for nine months of the year. As a result, indigenous peoples of the north experienced a disruption to the intergenerational transmission of their languages (Vakhtin, 2001, pp. 250-251; Zamyatin, 2012, pp. 19-20).

Owing to popular mobilization in the late 1980s and early 1990s, the Soviet and autonomous republics implemented programmes of national revival, with one of the goals being to promote learning in one's mother tongue. Following the collapse of the communist bloc and the disintegration of the Soviet Union, indigenous peoples were not recognized by successor States, nor by many newly independent countries. At least 80 per cent of the population of the Russian Federation identifies themselves as ethnic Russian, whereas at least 130 ethnicities can claim to be indigenous peoples. Some of the constituent entities of the Russian Federation are ethnically defined republics and autonomous districts, ${ }^{118}$ which are situated in three large areas: the European region (European north, Volga and Ural areas), the northern Caucasus and Siberia.

\section{Overview of indigenous peoples in the Russian Federation"19}

In the Russian Federation, legislation has accorded official recognition to indigenous groups that are smaller in number than 50,000, including those comprising just a few dozen persons, as "numerically small indigenous peoples of the Russian Federation" (hereinafter referred as "indigenous peoples", unless otherwise specified). Hence, only part of the legal and institutional framework for the larger- and small-numbered indigenous peoples is common to both groups. Currently, the unified list identifies 40 groups

118 Article 66 of the Constitution of 12 December 1993.

119 For relevant statistics on the ethnic composition and language proficiency of the population of the Russian Federation, see information materials on the final results of the 2010 All-Russian Population Census, appendices 5 and 6. Available at http://www.gks.ru/free_doc/new_site/perepis2010/perepis_itogi1612. htm (Excel files 5 and 6). 
of indigenous peoples of the north, Siberia and the far east and 7 groups residing elsewhere in the Russian Federation. In addition, the Republic of Dagestan compiled its own list of indigenous peoples which included groups with more than 50,000 people. ${ }^{120}$ Scholars question this definition of "indigeneity", as there are also significant groups of larger-numbered peoples, such as the Komi, the Yakuts and the Tuvans, that lead an indigenous traditional life.

The reason for a restrictive interpretation is that larger-numbered autonomous groups are better protected, within their "titular" regions. However, the titular group is a numerical minority in more than half of the 21 republics as well as in all four autonomous districts. The lowest numbers are in the Khanty-Mansi autonomous district, where indigenous peoples constitute approximately 2 per cent of the total population. Nevertheless, a comprehensive analysis of population census data reveals that even in those republics and autonomous districts where the titular groups remain politically marginalized, there are usually better language retention rates owing to accessibility of national schools (see, e.g., Khairullin, 2010, pp. 979-980).

The number of individuals officially belonging to the indigenous peoples increased in the last decade. In 2010 there were 316,000 indigenous peoples of whom 258,000 live in 28 regions in the north. ${ }^{121}$ The numbers increased among the Evenki, Evens, Khanty, Mansi, and Nenet in the republics and autonomous districts. This increase was due to a birth rate higher than the national average as well as the preference for indigenous iden-

At least 80 per cent of the population of the Russian Federation identifies themselves as ethnic Russian, whereas at least 130 ethnicities can claim to be indigenous peoples. Some of the constituent entities of the Russian Federation are ethnically defined republics and autonomous districts, which are situated in three large areas: the European region (European north, Volga and Ural areas), the northern

Caucasus and Siberia. tity by youth in mixed-marriage families, which can be attributed to access to benefits associated with indigenous status. At the same time, however, there are higher levels of infant and child mortality, disease incidence, illiteracy and unemployment among indigenous peoples (Arefiev, 2014, pp. 90-94; United Nations, Convention on the Rights of the Child, Committee on the Rights of the Child, 2012, para. 294).

During the mid-1950s, most indigenous peoples were fluent in their own languages. By the time of the collapse of the Soviet Union, however, there was a huge decline in native speakers. By 2010, the proportion of people with at least some knowledge

\footnotetext{
120 See the unified list of the indigenous small-numbered peoples of the north, Siberia and the far east of the Russian Federation, as approved by decree No. 255 of the President of the Russian Federation of 24 March 2000. Also see Rohr (2014), pp. 14-16; and Sokolovskiy (2011)

121 Calculation based on data from the 2010 population census.
} 
of an indigenous language had dropped to 22.7 per cent. Of those people, only 35.2 per cent indicated that they spoke the language of their group. Today, Russian is the first and main language for 90 per cent of indigenous peoples and many indigenous youths do not speak any indigenous language. On the other hand, a few indigenous languages, such as Nenets, are still used in those sectors of the traditional economy that benefit from the institutional support of the republics and autonomous districts (Vakhtin, 2001, pp. 224-225; Dikanskii and others, 2005, pp. 237-239). Overall, however, most indigenous languages are on the verge of extinction (Arefiev, 2014, p. 436; World Bank, 014, p. viii).

\section{Indigenous peoples and education in the Russian Federation}

\section{Access to and quality of education}

Indigenous peoples typically reside in areas with low population density and in isolated locations. In some cases, indigenous peoples maintain their nomadic or semi-nomadic lifestyles. During the post-Soviet period, many people left the north, which led to a drop in living standards, a decrease in the number of schools, students and teachers, and a deterioration of infrastructure. In the 2010-2011 academic year, fewer than two thirds of schools in the north had all necessary amenities, including water and central heating. These circumstances predispose to difficulties in providing indigenous children with access to quality educational services (Arefiev, 2014, p. 83).

\section{Preschool education}

Participation in preschool education in the Russian Federation is optional and less than two thirds of all indigenous children have access to public nurseries and kindergartens. The capacity of kindergartens remains insufficient, especially in remote regions, and less than 50 per cent of indigenous children attend kindergarten, mainly because their families have low incomes. Several regions have introduced compensation programmes, under which cash transfers are paid to parents whose young children are on a waiting list (Nikolaev and Chugunov, 2012, p. 15).

The model of 'nomadic kindergarten-school' was developed specifically to serve the needs of children of nomadic families. The purpose of such a school is to prepare children between the ages of three and six for entry into primary school through the use of the basics of indigenous pedagogy and indigenous language (Council of Europe, 2010, 
p. 50). The main goal is to enable children to attain fluency in communication skills in indigenous languages and to acquire skills and knowledge associated with traditional ways of life. Particular importance is placed on ensuring that children maintain daily contact with their parents. Among indigenous children between the ages of 1.5 and 7 years who attend kindergarten, only one sixth successfully learn their language, as there is an insufficient number of tutors who are fluent in the language and have a command of the necessary teaching methods (Arefiev, 2014, p. 444). The number of children learning indigenous languages in kindergarten is lower than in most non-nomadic schools, with most children in kindergarten instructed in Russian.

Attempts are being made to revitalize indigenous languages using new educational techniques within indigenous communities. The program utilizing the "language nest" technique, which is regarded as an effective language maintenance mechanism, is grounded in children's immersion in indigenous language. While this has been tested in several countries, it has yet to be fully taken on board in the Russian Federation (Council of Europe, 2010, pp.102-103). Nevertheless, the technique has proved appealing in some regions and there are plans to disseminate it in the Khanty-Mansi and Taimyr autonomous regions (Arefiev, 2014, pp. 204-205 and 248-249). The level of effectiveness of this program remains low owing to the teaching methods required. Since 2012, the Russian language has become compulsory in preschool institutions.

\section{Primary and secondary education}

Indigenous parents view education as the key determinant of the future of their children. However, the level of education among the indigenous peoples in the post-Soviet period has decreased. At least 48 per cent of indigenous youth have completed, or partially completed, only primary or secondary education, while 17 per cent do not have even a primary education. There is a lack of disaggregated data but from the information available, 89 per cent of school-age indigenous children in the north are receiving some form of schooling. In 2010, 1 per cent of adolescents and youth remained illiterate. Illiteracy is the highest among Nenets, Khanty and Evenki youth, the largest groups in the region. Experts have emphasized, however, that the problem is not illiteracy, but low-quality education. ${ }^{122}$

Authorities have suggested addressing the complex problem of low-quality education through utilization of small ungraded schools. These schools have less than the minimum of 14 pupils per class, which is a requirement according to federal educational standards. However, the regions can establish a lower minimum number of students if they wish to do so. The ungraded schools are situated in small indigenous communities and, typically, their classes include children of different age groups. They generally

122 Arefiev (2014), pp. 83-84 and 127-128. This author uses official regional data collected by the Ministry of Education. 
provide primary and, on rare occasions, secondary education. It is envisaged that these schools will be turned into local cultural centres comprising kindergarten, school, study groups, library, first-aid posts and facilities for leisure activities, all under one roof.

\section{Tertiary and vocational education}

Higher education is provided only in the Russian language. This is not the case, however, with respect to the training of mother-tongue teachers in local universities of the republics and other regions. There is a higher proportion of individuals with higher education among the larger-numbered peoples than among the ethnic Russians (for example, Yakuts and Buryats). Among small-numbered indigenous peoples, the proportion of individuals with higher education remains lower than the country average (Dikanskii and others, 2005, pp. 115-124).

Almost 10,000 indigenous children attend primary vocational schools while a somewhat smaller number attend secondary vocational schools. Three quarters of those who obtain a secondary professional or higher education are indigenous women, a proportion which is higher than the overall national average. Indigenous women are also predominantly teachers. In contrast, since the Soviet period, young indigenous men have been induced to confine their activities to the traditional economy, which generally does not require higher education. At present, consequently, indigenous men often find themselves in a disadvantaged position (Arefiev, 2014, pp. 127 and 142; Dikanskii and others, 2005, pp. 124-129 and 195-212).

Recently, the patterns of professional guidance and the educational aspirations of indigenous youth have changed dramatically. While fewer young people have the desire to commit themselves to a traditional way of life and wish, instead, to pursue other lifestyles in the larger cities, most parents want their children to obtain further vocational education. Employment in the legal and economics professions, as well as jobs in the oil industry, tend to enjoy the greatest popularity. The difficulty of this situation lies in the fact that employment opportunities in these professions may be scarce. The combination of lack of interest in activities in the traditional economy and few work opportunities often leads to social problems (Dikanskii and others, 2005, pp. 130-132).

The low quality of secondary education often prevents many young people from improving their quality of life through further education. To ensure access to higher education, some regions have established guarantees, including provision of special preparatory courses for undergraduate applicants, and ethnic quotas for special admission, as well as state support for indigenous students in the form of scholarships, compensation for travel expenses, provision of student housing and other social benefits (Dikanskii and others, 2005, pp. 139-142; Kriazhkov, 2010, p. 402).

An education for those who wish to become, for example, lawyers, economists and managers is offered at the State Polar Academy in Saint Petersburg and other institutions, 
in Khabarovsk, Krasnoyarsk and other cities, in accordance with agreements drawn up among educational institutions, the State and local authorities. The study programmes, however, rarely offer the type of education required for entry into the professions that are in demand in the north. The proportion of indigenous students who do not complete their course work is higher than average. For example, the proportion was three times higher than the national average in the former Koryak autonomous region, where less than one third of indigenous Shor students graduated from the Kuzbass State Pedagogical Academy (Dikanskii and others, 2005, pp. 136-142).

\section{Indigenous education systems and mainstream education}

Within the public education system, indigenous children attend boarding and nomadic schools. Indigenous non-governmental organizations have criticized boarding schools for breaking the link between children and their families and traditional ways of life, which often causes psychological damage. ${ }^{123}$

Despite the criticism, there have been no further developments on proposals for alternative teaching methods and different curricula in accordance with relevant laws (Kriazhkov, 2010, p. 405). Some regions, such as the Republic of Sakha (Yakutia), have passed their own legislation. For example, the nomadic school system which had been in operation during the 1930s was reintroduced in the early 1990s. Schools began to operate without separating children from their parents and reintroduced linkages to their traditional way of life. Parents requested the municipal authorities to create nomadic schools which would offer residential sessions in host schools with visiting teachers, with educational content and educational process were adapted to the traditional calendar. Other initiatives include parental teaching and distance learning through the Internet based on individual study plans in compliance with state educational standards. ${ }^{124}$

In Sakha, where there are indigenous communities, nomadic schools have been created either as separate educational establishments or as branches of existing schools. The models for school branches include nomadic schools, primary nomadic kindergarten-schools, community schools, tutor schools, Taiga schools, Sunday schools and summer nomadic schools. Stationary nomadic schools and network nomadic schools are the models for separate institutions. Teachers must obtain a special professional

\footnotetext{
123 See, for example, the non-Governmental organization alternative report containing parallel information, with reference to the combined fourth and fifth periodic report of the Russian Federation (CRC/C/RUS/45), on "Children belonging to the indigenous small-numbered peoples of the north, Siberia and the far east of the Russian Federation" (21 November 2013). Submitted to the Committee on the Rights of the Child at its sixty-fifth session (13-31 January 2014) on behalf of the Russian Association of Indigenous Peoples of the North (RAIPON), the International Work Group for Indigenous Affairs (IWGIA) and the Institute for Ecology and Action Anthropology (INFOE)

124 Articles 1 and 13 of the law of 22 July 2008; Dikanskii and others, 2005, pp. 109-111; Robbek and other, 2009
} 
education, with training arranged through public contracts. Parents may perform as teachers in Taiga schools and network nomadic schools in the capacity of "consultant-tutors". Educational establishments have recently allowed indigenous languages to be taught by teachers who may not necessarily be qualified as language teachers. ${ }^{125}$ A 2012 federal law approved a form of family education and as a result, a new type of school - the family nomadic school - was introduced in Sakha. ${ }^{126}$

The number of nomadic schools has grown (Funk, 2012, p. 60). In the Sakha (Yakutia) Republic, there were 4 nomadic schools in 1990-91, 10 in 2007-08 and 13 in 2011-12. In school year 2011-12, there were four nomadic kindergartens, and three Summer and six stationary nomadic schools. Most schools teach reindeer-herding and a few teach fishing or hunting. All of the schools offer primary education and some also provide preschool or secondary education. ${ }^{127}$ Nomadic schools were also launched in the Yamalo-Nenets and Khanty-Mansi autonomous regions, the Taimyr and Evenk former autonomous regions and the Amur Oblast (Arefiev, 2014, pp. 189, 207, 249-255, 264-265 and 326-327). However, some parents perceive nomadic schools to be yet another novel administrative invention imposed "from above". Parents are used to sending children to boarding schools as exemplifying a form of state paternalism, which leaves them with extra time and financial aid and frees them from responsibility. Administrations often prefer to maintain boarding schools because they require fewer funds per capita, which is an important efficiency indicator in the reformed system, while the maintenance of nomadic and small rural schools is costlier.

Non-formal education - or "additional education" as it is called in the Russian Federation - is considered an integral part of formal education, with the State playing a primary role. In order to become a teacher in an institution of additional education, a professional pedagogic education is required. This formal requirement results in the exclusion of elders and other members of indigenous communities, thereby disrupting the transmission of traditional knowledge. Russian legislation allows for the creation of private educational institutions, for example, by national-cultural autonomous districts or indigenous communities. However, the size of the private education sector is negligible, with less than 1 per cent of pupils in the country enrolled in private preschool institutions and schools in 2012. ${ }^{128}$ Often lacking financial resources, indigenous peoples prefer to make use of all possible options available within the public education sphere.

\footnotetext{
125 Article 2 and 10 of the law of 22 July 2008; article 19 of the law of 15 December 2014; Council of Europe, 2010, p. 50 . 


\section{Indigenous perspectives in mainstream education}

Regular public schools situated in ethnically defined localities have been traditionally classified as "national schools". Such schools use either an ethnic regional language or Russian as the medium of instruction. In localities with mixed populations, regular "Russian" schools sometimes include other languages and multicultural subjects in the curriculum. Such schools often have "national classes" where students study the local ethnic language as a compulsory subject. In both types of schools, children study the history and geography of the region and the culture of its peoples, including games, the arts and ethnic sports. In the north, schoolchildren also acquire skills related to reindeer herding, hunting, fishing, ethnic technologies and other traditional knowledge, with a focus on work experience (see Zamyatin, 2012).

The Russian Federation has a single school curriculum which is both obligatory as well as flexible. The obligatory component is designed by federal authorities in consultation with regional authorities. The teaching of languages other than Russian and literature is provided in some schools, depending on the chosen syllabus. The flexible component, which accounts for 20 per cent of the syllabus in primary school and 30 per cent in basic secondary education, is developed by students, parents, teachers and schools. While parents may request the school to include language learning and other study subjects, they do not make the final decisions (United Nations, General Assembly, Human Rights Council, 2010, paras. 67 and 94; Prina, 2014, p. 15). In practice, parents are typically unaware of their rights or fail to adopt a collective position on the board, which requires the support of the parents of 25 students in urban schools and 14 in rural ungraded schools. It is usually the school administration that makes the decisions regarding the inclusion of flexible modules designed to meet the needs of children, which vary within and among schools. ${ }^{129}$ As a result, many schoolchildren lack access to multicultural education.

The fact that there are practically no textbooks available on the history of indigenous peoples of the north renders those peoples largely invisible. Regional textbooks must undergo examination at four levels of federal expertise, including ethnocultural expertise, to be entered into the list of textbooks that have been federally approved and recommended for use in the classroom, which makes it difficult to issue new textbooks. However, aspects of indigenous history are taught in some autonomous districts through courses on culture. ${ }^{130}$

Currently one tenth of children of non-Russian ethnicity study in their native languages. Education delivered in non-Russian languages is organized only in the republics, mostly in rural schools in Bashkortostan, Kalmykia, Sakha (Yakutia), Tatarstan, Tuva and, to a lesser extent, urban schools (Arefiev, 2014, pp. 110-113).

129 Articles 28 and 44 of the federal law of 29 December 2012; Zamyatin (2012), pp. 33-34.

130 Article 18 of the federal law of 29 December 2012; Kriazhkov (2010), p. 28. 
In the Russian Federation, there is currently no instruction provided in the languages of the small-numbered indigenous peoples, which are taught as optional subjects only. Their teaching is usually organized in local schools in the areas where indigenous peoples reside, including boarding and nomadic schools. Out of 40 indigenous languages in the north, only 23 are taught as a compulsory subject. Five are taught as an optional subject, while the rest are not taught at all. The federal statistics service and the federal education ministry collect information on the use of languages in education based on the data from the regions. The ministry does not collect data on ethnicity, and only estimates can be produced on the number of students who are learning their own language (Zamyatin, 2012, pp. 40-42).

During academic year 2001-02, a total of 20,406 students in 284 schools had been taught indigenous languages as a compulsory subject. Indigenous languages were taught to 14,115 students in 215 schools in 2012-13; and in the same period, the number of indigenous students who were learning their language as a subject decreased from 48.7 to 41.5 per cent. The number is further decreasing owing primarily to the closure of small ungraded schools. From 2001-02 to 2012-13, the number of students who were learning their language as an optional subject doubled, including in facilities of additional education. A change in the number of students learning their language as a compulsory subject and those learning their language as an optional subject might be an outcome of education reform (Arefiev, 2014, pp. 119, 142 and 438; Zamyatin, 2012, pp. 40-42).

The linguistic and educational needs of indigenous peoples who live outside their communities, in towns and urban settlements, are not addressed. They constitute approximately one third of the entire indigenous population in the country (World Bank, 2014, p. viii). In urban areas, the number of indigenous students who can learn their languages is very small (Arefiev, 2014, pp. 120-123). Moreover, in situations where language classes are available at urban schools, language instruction is considered an extracurricular activity is taught as an optional subject for one hour per week. To take advantage of this opportunity, children are obliged to stay after school in study circles or additional education establishments.

The low social status of indigenous languages provides no incentives for language learning. Most students lack a linguistic environment at home and possess no prior knowledge of an indigenous language. They must therefore learn an indigenous language as a foreign language. Among those with access to language learning, only a few will have acquired good language competence or even communicative skills upon school completion, an outcome that is due partly to ineffective methodology (Dijanskii and others, 2005, pp. 230-233). 


\section{Governance, policies and legislation}

\section{Legislation}

The Russian Constitution recognizes the right to education. This right is guaranteed through universal and free-of-charge access to preschool, primary and secondary general and professional education within public educational institutions and enterprises. The State also guarantees free access to higher education on a competitive basis. ${ }^{131}$

The Russian Federation has committed to the universally recognized principles and norms of international law in protecting the rights of indigenous peoples. Indigenous peoples have the right to receive state support for education of the younger generations, while considering the specific characteristics of their traditional livelihoods. They also have the right to create their own study groups for teaching traditional economic activities and trades. ${ }^{132}$

\section{Educational policy, education reform}

Since 2001, the modernization of education has become a policy goal, with general education being financed from regional and municipal budgets. Over the past few years, competition over federal funding needed to modernize the system of education-related governance has led regional authorities to introduce performance-based teacher salaries and per-student school financing (Nikolaev and Chugunov, 2012, pp. 27-31).

In 2001, ungraded schools constituted 70 per cent of all schools and accounted for 30 per cent of students and 40 per cent of teachers. ${ }^{133}$ However, since 2001, the number of school-age children in the Russian Federation has dropped by almost half. The restructuring of the school system through "optimization" of regional education systems, initiated in 2008, has had a disproportionate effect on national schools, since most of them are ungraded rural schools which do not satisfy the new funding criteria (Council of Europe, Advisory Committee on the Framework Convention for the Protection of National Minorities, 2012, paras. 192-193). During the period from 2006-2007 and 20132014 , the number of small ungraded schools in the areas of indigenous traditional activities dropped from 300 to about 250 (Arefiev, 2014, p. 126).

In 2007, through education reform, the national-regional component of the state education standards was eliminated. In compliance with the new unified federal education standards, regional education agencies developed the main educational programmes

\footnotetext{
131 Article 43 of the Constitution of 12 December 1993; article 5 of the federal law of 29 December 2012.

132 Article 69 of the Constitution of 12 December 1993; articles 8 and 10 of the federal law of 30 April 1999. 133 Government Decree of 17 December 2001.
} 
and core curricula that define the scope (number of hours) and structure (list of subjects) of studies and facilitate their implementation. While the educational programmes can still include multicultural subjects, the regional education agencies have lost their power to make those subjects compulsory and educational establishments enjoy relative autonomy in determining the content and methods of education (Zamyatin, 2012, pp. 38-40).

If there is sufficient parental demand, schools will provide educational services and decide on the language of instruction and the teaching of multicultural subjects. The third sample syllabus of the federal basic curriculum applies to schools where native language and literature are taught as subjects; and the fourth applies to schools offering indigenous language instruction. Usually, three to five hours per week are allotted to indigenous language learning in the republics and from one to three hours per week are allotted in autonomous districts and other regions (Zamyatin, 2012, pp. 36-37 and 40-42).

Recently, nation-building was officially declared to be the first goal of the policy of nationalities and the maintenance and development of multicultural diversity were declared to constitute the second. ${ }^{134}$ Under education policy, the unity of the educational space is emphasized in conjunction with the protection and cultivation of the multicultural traditions of the peoples of the Russian Federation, including those traditions' characteristic features. ${ }^{135}$ The promotion of the dominant language and a unified vision of history attest to the aim of achieving homogenization of the population. ${ }^{136}$

\section{Institutional and structural support}

\section{Institutional support}

Federal law provides significant support for the teaching of non-Russian languages and other specifically ethnic or cultural subjects. ${ }^{137}$ In ethnically defined regions, this is achieved through the implementation of regional programmes targeted at financing, inter alia, for the purchase of textbooks, training manuals and dictionaries, and for the salaries and, in some cases, the bonuses of teachers with knowledge of languages. Research institutions, such as the Institute of Education of the Small-numbered Indigenous Peoples at the Russian Academy of Education and the Institute of National Schools of the Republic of Sakha (Yakutia), have developed multicultural content and new modalities for education.

\footnotetext{
134 Strategy of the State Nationalities Policy of 19 December 2012.

135 Article 3 of the federal law of 29 December 2012.

136 Government order of 3 August 2006; Zamyatin (2012), pp. 29-30.

137 Article 263 of the Federal law of 6 October 1999; article 8 of the Federal law of 29 December 2012.
} 
One means of ensuring continuity between secondary and tertiary education is to produce qualified teachers. The training of indigenous teachers for work in preschool, schools and vocational institutions has been formally implemented in the Institute of the Peoples of the North at Herzen Russian State Pedagogical University. Following the introduction of the Bologna system in the Institute during 2009-2010, a new requirement established a 10 to 1 ratio of students to university instructors, which increased the difficulty of training teachers of most indigenous languages. Teacher training in master's-level studies has not yet begun; and training of preschool tutors was terminated, as it was determined that they no longer required higher education (Arefiev, 2014, pp. 145-148 and 445; Dijanskii and others, 2005, pp. 142-145).

The sense of alienation from their roots experienced by indigenous students, coupled with the fact that children of mixed heritage may be studying far from their linguistic and cultural environment, has resulted in a decrease in the number of individuals who return to their homelands. Teacher training in regional institutes is one means of solving this problem. Currently, future teachers of indigenous languages, literature and culture are being trained at regional institutes such as the Amosov North-Eastern Federal University, Yugor State University, Far Eastern Federal University, Petrozavodsk State University, Buryat State University and Kuzbass State Pedagogical Academy. However, there continues to be a lack of young, qualified teachers in many other regions. In total, there are about 350 full-time and 150 part-time indigenous language teachers whose median age is close to 50. Distance learning has also been proposed as an alternative solution (Arefiev, 2014, pp. 148-152; Dijanskii and others, 2005, pp. 277-279 and

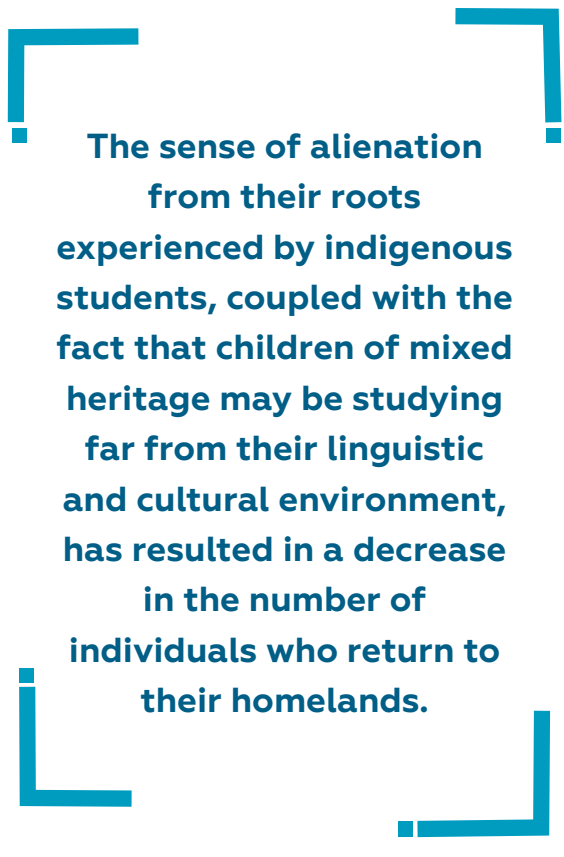
283-287).

\section{Structural support}

The inter-institutional efforts to support indigenous peoples in the north are coordinated through the concept of sustainable development of the indigenous small-numbered peoples of the north, Siberia and the far east of the Russian Federation, as approved by decree No. 132 of the Government of the Russian Federation of 4 February 2009. The goal is to improve indigenous peoples' access to educational services by considering their specific socio-cultural needs. The first action plan for the implementation of the concept, as approved by order No. 1245 of the Government of the Russian Federation of 28 August 2009, included measures for the delivery of high-quality education such as 
professional teacher training and provision of schools with modern equipment encompassing computerization and Internet access. The action plan also enabled distance learning to be implemented by the Ministry of Education and Science. ${ }^{138}$

Some international funding is available, for example, through a United Nations Educational, Scientific and Cultural Organization UNESCO-funded project entitled "Promoting the literacy of indigenous pupils through capacity building among nomadic peoples of the north of the Republic of Sakha (Yakutia)" and a World Bank-funded project entitled "Innovative development of the system of preschool education in the Republic of Sakha (Yakutia)" (see Robbek and others, 2009; World Bank, 2014, p. 31).

\section{Main findings}

The programme for providing indigenous peoples with access to education in the Russian Federation suffers from some significant deficiencies in terms of both its quality and its content. While the establishment of the particular types of schools needed to meet the needs of indigenous peoples is permitted, those schools must remain within the integrated educational space and often face financial difficulties. Efforts to transmit traditional knowledge using indigenous pedagogy in the formal education system are centred mostly on nomadic children with involvement of indigenous teachers. School curricula may include a multicultural component, but indigenous peoples do not participate directly in the development of those curricula.

Learning indigenous languages as a subject is not available to some indigenous smaller-numbered peoples. In this regard, the proportion of students among indigenous peoples of the north who have the opportunity to learn their indigenous languages is close to 40 per cent and is currently decreasing.

While the right to education is outlined in legislation, the exercise of this right in practice remains a concern. During the last decade, education reforms have reinforced Russian as the state language. The nation-building agenda envisages education as the central tool for identity construction. The closure of small ungraded schools has reduced access to education in the regions and has had an impact on the use of indigenous languages as a means of instruction.

Institutional support for multicultural education is provided mainly at the regional level. It is the regional authorities that are responsible for taking into account the linguistic and ethnocultural demands of their populations. The level of support, including provision of funds, varies across regions and depends on economic conditions and the

138 Government decree of 4 February 2009; Government order of 28 August 2009 
responsiveness of their authorities. In many instances, there is a lack of qualified teachers and up-to-date teaching materials. Specialized public bodies at the federal level provide structural support for coordinated efforts across regions; international support for efforts at the regional and national levels is also important in this regard.

In the Russian Federation, the Constitution and national legislation set out the rights of indigenous small-numbered peoples of the north. At the same time, the level of education of indigenous peoples is lower than the average, and indigenous students have little or no opportunities for learning their own languages. Many indigenous peoples must face the fact that their ancestral language and traditional values have or are in danger of being lost. Racism and xenophobia in society at large as well as dominant language ideologies reinforce stereotypes and discriminatory attitudes towards indigenous education.

While some good school models do exist in the Russian Federation, inadequate development of appropriate preschool facilities for indigenous children remains an issue. The nomadic kindergarten-school model represents an important contribution to the education of nomadic boys and girls.

\section{Recommendations}

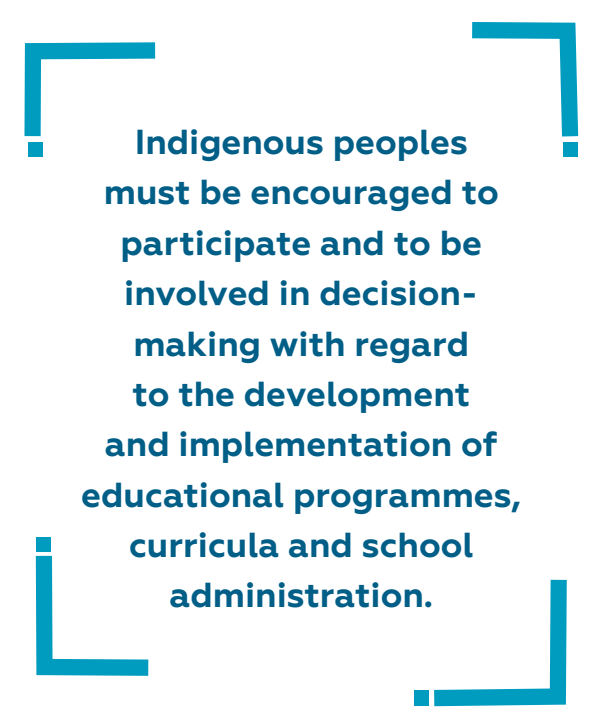

1. The Government should provide disaggregated data on the number of students who attend small ungraded schools, nomadic schools and boarding schools across the regions. These schools provide the opportunity for children to remain in their communities and receive an education locally. The use of boarding schools for nomadic indigenous children should be minimized;

2. Indigenous peoples must be encouraged to participate and to be involved in decision-making about the development and implementation of educational programmes, curricula and school administration. Indigenous parents need to be made aware of their right to request the inclusion of indigenous languages and other ethnocultural subject-matter;

3. There is a need to raise awareness among indigenous peoples of the opportunities for learning their own languages and to encourage the value of bilingualism. Authorities should ensure that education reform does not result in the diminishment of ethnically oriented education and the decrease of number of small ungraded schools which support indigenous students. 
The State should facilitate the upgrading of small rural schools into centres of local cultural life, where indigenous peoples' languages and traditions are maintained, and should facilitate the development of networking among such schools;

4. Best practices and initiatives on appropriate teaching methodologies, training of qualified teachers and preparation of supplies and materials should be approved at the federal level and extended to the various regions of the country. The use of innovative models, such as nomadic schools and the language nest, should also be supported. Indigenous peoples' perspectives on pedagogy and knowledge should be included in the development of educational programmes and bilingual education, to ensure that all languages enjoy the same level of importance. The teaching administration should consider the psychological, linguistic and cultural demands of indigenous children; and

5. The authorities should ensure continuity in the provision of ethnocultural and polycultural education and should encourage all children to participate in such programmes. 


\section{References}

Arefiev, A.L. (2014). lazyki korennykh malochislennykh narodov Severa, Sibiri i Dalnego Vostoka v sisteme obrazovaniia: istoriia i sovremennost. Moscow: Social Forecasting and Marketing Centre.

Council of Europe (2010). Third report submitted by the Russian Federation pursuant to article 25, paragraph 1, of the Framework Convention for the Protection of National Minorities. 9 April. ACFC/SR/III(2010)005.

Advisory Committee on the Framework Convention for the Protection of National Minorities (2012). Third opinion on the Russian Federation adopted on 24 November 2011. 25 July. ACFC/OP/III(2011)010.

Dikanskii, N.I., and others (2005). Obrazovanie dlia korennykh narodov Sibiri. Sotsiokulturnaia rol Novosibirskogo gosudarstvennogo universiteta. Novosibirsk, Russian Federation: Nonparelle.

Funk, D.A. (2012). Sokhranenie i razvitie iazykov korennykh malochislennykh narodov Severa Rossiiskoi Federatsii. In Sever i severiane: sovremennoe polozhenie korennykh malochislennykh narodov Severa, Sibiri i Dalnego Vostoka Rossii, N. Novikova and D. Funk, eds. Moscow: Russian Academy of Science, Institute of Ethnology and Anthropology. pp. 37-44.

International Federation for Human Rights (FIDH) (2013). Discrimination against visual minorities, Roma, migrants and indigenous peoples: Russia's record before the United Nations. Paris. 13 February.

Khairullin, R.Z. (2010). Sotsialno-pedagogicheskie problemy obrazovaniia korennykh narodov Severa (Social- pedagogical problems of education for indigenous people of the north). In Regiony Rossii dlia ustoichivogo razvitiia: obrazovanie $i$ kultura narodov Rossiiskoi Federatsii, I. Graf and N. Dulepova, eds. Proceedings of the international conference held from 25 to 27 March 2010. Novosibirsk, Russian Federation: Ofset Publishing, pp. 978-989.

Kriazhkov, V.A. (2010). Korennye malochislennye narody Severa v rossiiskom prave. Moscow: Norma.

Martin, Terry (2001). The Affirmative Action Empire: Nations and Nationalism in the Soviet Union, 1923-1939. Ithaca, New York: Cornell University Press.

Nikolaev, Denis, and Dmitry Chugunov (2012). The Education System in the Russian Federation. Education brief No. 67864 (2012). Washington, D.C.: World Bank.

Prina, Federica (2014). Protecting the Rights of Minorities and Indigenous Peoples in the Russian Federation: Challenges and Ways Forward. Budapest: Minority Rights Group Europe. November.

Robbek, Vassily A., and others (2009). Promoting educational access for the indigenous reindeer herders, fisherpeople and hunters in the nomadic schools of Yakutia, Russian Federation. In Traveller, Nomadic and Migrant Education, Patrick 
Alan Danaher, Máirín Kenny and Judith Remy Leder, eds. New York: Routledge. Chap. 14, pp. 74-86.

Rohr, Johannes (2014). Indigenous Peoples in the Russian Federation. IWGIA report No. 18. Copenhagen: International Work Group for Indigenous Affairs.

Sokolovskiy, Sergey V. (2011). Russian legal concepts and indigenous peoples demography. Indigenous Peoples and Demography: The Complex Relation between Identity and Statistics, Per Axelsson and Peter Sköld, eds. New York: Berghahn Books, pp. 239-251.

Strogalshchikova, Z.I. (2013). levropeiskaia khartiia regionalnykh iazykov i iazykov menshinstv kak vazhnyi mekhanizm zashchity iazykov korennykh malochislennykh narodov Rossii. In Sovremennoe sostoianie i puti razvitiia korennykh malochislennykh narodov Severa, Sibiri i Dalnego Vostoka Rossiiskoi Federatsii, V.A. Shtyrov, ed. Moscow: Federation Council, pp. 188-197.

United Nations, Convention on the Rights of the Child, Committee on the Rights of the Child (2012). Combined fourth and fifth periodic reports of the Russian Federation due in 2011 under the Convention on the Rights of the Child. 27 August. CRC/C/ RUS/4-5.

(2014). Concluding observations on the combined fourth and fifth periodic reports of the Russian Federation. 25 February. CRC/C/RUS/CO/4-5.

United Nations, Economic and Social Council, Committee on Economic, Social and Cultural Rights (2010). Fifth periodic report submitted by the Russian Federation on the implementation of the International Covenant on Economic, Social and Cultural Rights. 25 January. E/C.12/RUS/5.

United Nations, Economic and Social Council, Permanent Forum on Indigenous Issues (2010). Note by the Secretariat on indigenous peoples and boarding schools: a comparative study. 1 February. E/C.19/2010/11.

United Nations, General Assembly, Human Rights Council (2010). Addendum to the report of the Special Rapporteur on the situation of human rights and fundamental freedoms of indigenous people, James Anaya, on the situation of indigenous peoples in the Russian Federation. 23 June. A/HRC/15/37/Add.5.

(2013). National report submitted by the Russian Federation in accordance with paragraph 5 of the annex to Human Rights Council resolution 16/21. 6 February. A/HRC/WG.6/16/RUS/1.

United Nations, International Convention on the Elimination of All Forms of Racial Discrimination, Committee on the Elimination of Racial Discrimination (2012).

Twentieth to twenty-second periodic reports of the Russian Federation submitted under article 9 of the Convention. 6 June. CERD/C/RUS/20-22.

(2013). Concluding observations on the twentieth to the twenty-second periodic reports of the Russian Federation, adopted by the Committee on the Elimination of Racial Discrimination at its eighty-second session (11 February-1 March 2013). 17 April. CERD/C/RUS/CO/20-22. 
Vakhtin, N.B. (2001). lazyki narodov Severa v XX veke. In Ocherki iazykovogo sdviga. Saint-Petersburg, Russian Federation: European University, Saint Petersburg.

World Bank (2014). Indigenous peoples of Russia: country profile. Working paper No. 89151. Washington, D.C. June.

Zamyatin, Konstantin (2012). The education reform in Russia and its impact on teaching of the minority languages: an effect of nation-building? Journal on Ethnopolitics and Minority Issues in Europe, vol. 11, No. 1, pp. 17-47.

\section{Relevant legislation and instruments}

Action plan aimed at the implementation in 2009-2011 of the concept of sustainable development of the indigenous small-numbered Peoples of the north, Siberia and the far east of the Russian Federation, as approved by order No. 1245 of the Government of the Russian Federation of 28 August 2009

Concept of the National Education Policy of the Russian Federation, as approved by order No. 201 of the Ministry of Education of the Russian Federation of 3 August 2006

Concept of the sustainable development of the indigenous small-numbered peoples of the north, Siberia and the far east of the Russian Federation, as approved by decree No. 132 of the Government of the Russian Federation of 4 February 2009

Decree No. 871 of the Government of the Russian Federation on the restructuring of the network of educational institutions situated in the rural areas of 17 December 2001

European Charter for Regional or Minority Languages (ETS No. 148). Drawn up on the basis of a text put forward by the Standing Conference of Local and Regional Authorities of Europe, adopted as a convention on 25 June 1992 by the Committee of Ministers of the Council of Europe, and opened for signature on 5 November 1992. The Charter entered into force on 1 March 1998. Date of signature by the Russian Federation: 10 May 2001. Not ratified

Federal law No. 82 of the Russian Federation on guarantees of the rights of the indigenous small-numbered peoples of the north, Siberia and the far east of 30 April 1999

Federal law No. 121 of the Russian Federation on regulation of activities of noncommercial organizations performing the function of foreign agents of 20 July 2012

Federal law No. 184 of the Russian Federation on general principles for the organization of legislative (representative) and executive authorities in the subjects of 6 October 1999

Federal law No. 273 on education in the Russian Federation of 29 December 2012

Framework Convention for the Protection of National Minorities (European Treaty Series (ETS), No. 157). Drawn up within the Council of Europe by the Ad Hoc Committee for the Protection of National Minorities, under the authority of the Committee of Ministers, and adopted by the Committee of Ministers of the Council of 
Europe on 10 November 1994 and opened for signature by the member States of the Council of Europe on 1 February 1995. Date of signature by the Russian Federation: 28 February 1996; date of ratification by the Russian Federation: 21 August 1998

Framework of measures taken in the Russian Federation for 2011-2014 in connection with the Second International Decade of the World's Indigenous People, as approved by order No. 2455 of the Government of the Russian Federation of 28 December 2010

Law No. 1807-I of the Russian Soviet Federative Socialist Republic on the languages of the peoples of the Russian Soviet Federative Socialist Republic of 25 October 1991

Resolution CM/ResCMN(2013)1 of the Committee of Ministers of the Council of Europe on the implementation of the Framework Convention for the Protection of National Minorities by the Russian Federation of 30 April 2013

State Assembly Press Service information presented at the parliamentary hearings of the State Assembly (Il Tumen) of the Republic of Sakha (Yakutia) on the implementation of the law on nomadic schools, held on 6 December 2011

Strategy of the state nationalities policy of the Russian Federation for the period up to 2025, as approved by decree No. 1666 of the President of the Russian Federation of 19 December 2012

Unified list of the indigenous small-numbered peoples of the north, Siberia and the far east of the Russian Federation, as approved by decree No. 255 of the President of the Russian Federation of 24 March 2000 